\title{
Comparative pharmacognostic evaluation of Tecomella undulata and Rhododendron arboreum as two different sources of Rohitaka
}

\author{
Puneshwar Keshari', Pradeep 1 , Suchitra N Prabhu²
}

\begin{abstract}
${ }^{1}$ Department of Dravyaguna, SDM College of Ayurveda and Hospital, Hassan, Karnataka, India, ${ }^{2}$ Department of Pharmacognosy and Phytochemistry, SDM Centre for Research in Ayurveda and Allied Sciences, Kuthpady, Udupi, India
\end{abstract}

\begin{abstract}
Background: Tecomella undulata ( $\mathrm{Sm}$.) Seem. is considered as a genuine source of Rohitaka which is mentioned in Ayurveda classics for Yakrit Pliha Roga (liver and spleen diseases). In different parts of India, various other species are used as substitute of Rohitaka due to non-availability of the genuine source. In Nepal, folklore traditional practitioners use Rhododendron arboreum Sm. for the treatment of jaundice and it is marketed by the name of Rohitaka. Objective: The present study outlines the concept of substitution. The stem bark of T. undulata $(\mathrm{Sm}$.) Seem. and R. arboreum $\mathrm{Sm}$. is compared on the basis of macroscopic/organoleptic evaluation, microscopic evaluation, physicochemical analysis, phytochemical analysis, and high-performance thin-layer chromatography (HPTLC). Materials and Methods: Macroscopic/organoleptic evaluation, microscopic evaluation, and physicochemical and preliminary phytochemical screening were carried out using standard methods. Semi-automatic applicator was used for HPTLC profiling. Results: Macroscopic/organoleptic evaluation showed longitudinally fissured and fibrous fracture in T. undulata with bitter taste, while longitudinally furrowed, laminated bark with bitter taste in $R$. arboreum. Powder microscopy revealed the presence of parenchyma with starch, parenchyma with cell content, and cork cells in both drugs. On physiochemical analysis, T. undulata showed greater water and alcoholic extractive value than $R$. arboreum. Carbohydrates, alkaloids, tannins, and phenols were the chemical constituents found in both the drugs. HPTLC study revealed that there are 18 active phytoconstituents in $R$. arboreum barks and 24 in $T$. undulata on the basis of peaks observed. Conclusion: The present study revealed few common phytoconstituents found in both T. undulata and R. arboreum.
\end{abstract}

Key words: High-performance thin-layer chromatography, phytoconstituents, Rhododendron arboretum, Rohitaka, Tecomella undulate, Yakrit-pleeha Roga

\section{INTRODUCTION}

$R$ ohitaka is mentioned in almost all classics of Ayurveda such as Brihattrayee (Charaka Samhita, Sushruta Samhita, and Ashtanga Hridya $)^{[1-3]}$ and other lexicons such as Sharangdhara Samhita, Bhavaprakasha Nighantu, and Yoga Ratnakar. ${ }^{[4-6]}$ It is also mentioned in maximum numbers of Nighantu (Ayurvedic lexicons). It is mentioned as Yakritpleehagulmodar Roga-hara $^{[7,8]}$ (useful in liver diseases, spleen disorders, and abdominal lumps).

Tecomella undulata (Sm.) Seem. from Bignoniaceae family is a genuine source of Rohitaka ${ }^{[9,10]}$ It is commonly known as "Rohida" or "Desert Teak" and an important deciduous, ornamental, and medicinal tree. ${ }^{[11]}$ This species is an evergreen tree which grows in tropical regions and forms spots on its growing area, and it may reach a height of $12 \mathrm{~m}$ and diameter of $2.4 \mathrm{~m} \cdot{ }^{[12]}$ It has antibacterial, antifungal, antiviral, antifertility, hypoglycemic, central nervous system depressant, anticancer, hepatoprotective, hypotensive, muscle relaxant, cardiac depressant, diuretic, and analgesic activities. ${ }^{[10]}$ The

\author{
Address for correspondence: \\ Dr. Puneshwar Keshari, Department of Dravyaguna, \\ SDM College of Ayurveda and Hospital, \\ Hassan - 573 210, Karnataka, India. \\ Phone: +91-9148816405. \\ E-mail: dr.puneshwarkeshari@gmail.com
}

Received: 11-04-2018

Revised: $10-10-2018$

Accepted: 06-11-2018 
species of T. undulata is restricted to the drier parts of Arabia, Southern Pakistan, and Northwest India. In India, it occurs naturally in Maharashtra, Gujarat, Rajasthan, Punjab, and Haryana. ${ }^{[13]}$ This species has been considered as threatened in Rajasthan province of India. The United Nations Environment Program's World Conservation Monitoring Centre at Nairobi, Kenya, has included it under category I-Indeterminate, to stop further exploitation of this species. It is also listed as rare at the

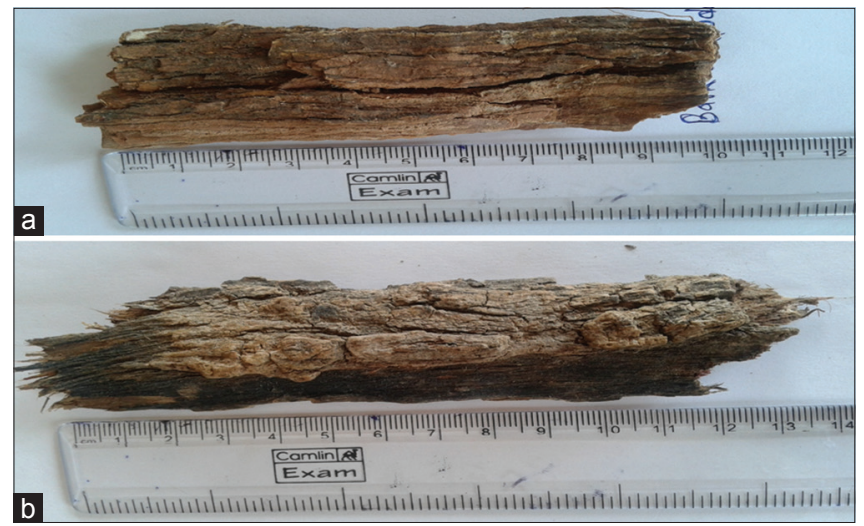

Figure 1: Macroscopic characters of barks of test drugs. (a) Bark of Rhododendron arboretum, (b) bark of Tecomella undulata outer surface

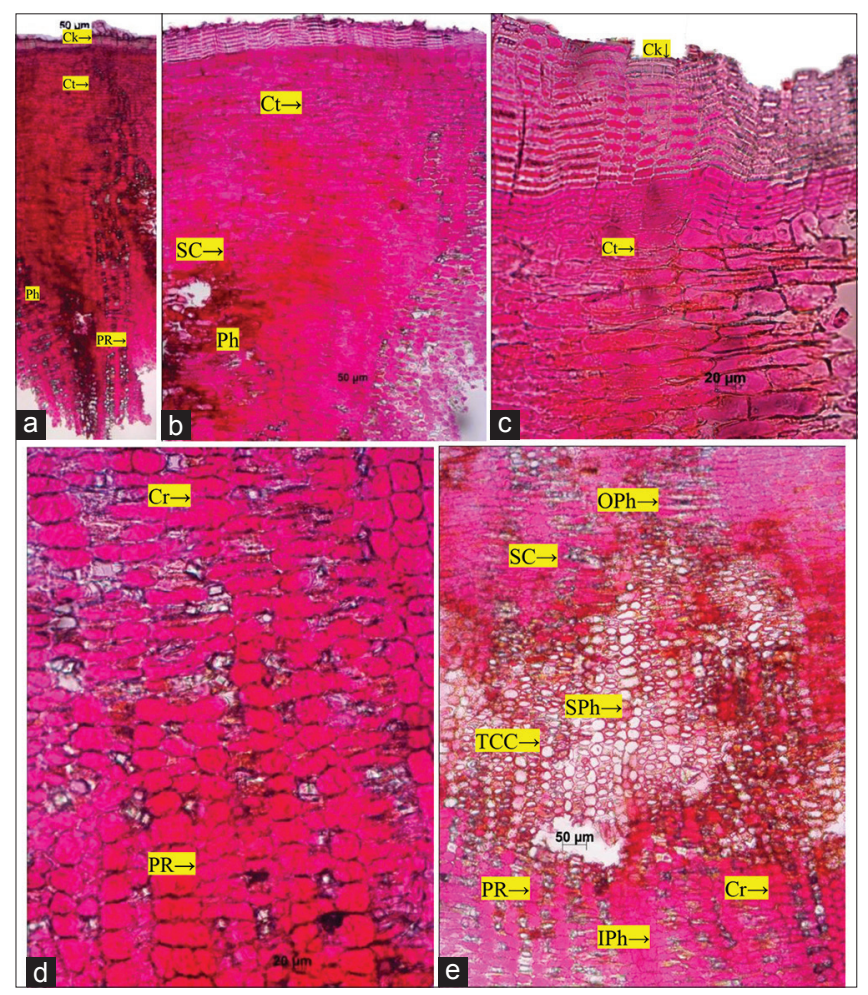

Figure 2: (a) TS of the entire bark of Rhododendron arboretum, (b) TS of the entire bark of Rhododendron arboretum, (c) Cork and cortex bark of Rhododendron arboreum, (d) A portion of phloem, (e) Outer phloem and inner phloem, $\mathrm{Ck}$-cork, $\mathrm{Cr}$-crystals of calcium oxalate, Ct-cortex, IPh - inner phloem, PF - phloem fibers, PR - phloem ray, OPh - outer phloem, SPh - secondary phloem, SC-stone cells, TCC - tannin containing cells international level (IUCN, 2000). ${ }^{[12,14]}$ Due to non-availability of genuine source of Rohitaka (T. undulata [Sm.] Seem.), various other drugs are used by the name of Rohitaka. Aphanamixis polystachya (Wall.) Parker (syn. Amoora rohituka W.\& A.) is commercially used substitute. Erythrina variegata Linn. var. orientalis (L.) Merril. is sold in drug market of North India under the name of Rohitaka. ${ }^{[10]}$

The Acharyas of Ayurveda had treasured the unique concept of "Abhava Pratinidhi Dravya" ages ago. As per the

\begin{tabular}{ll} 
Table 1: Macroscopic characteristics of stem bark of \\
Rhododendron arboreum Sm. \\
Shape & Flat, slightly curved \\
Size & $9-10 \mathrm{~cm}$ \\
Surface & Longitudinally ridged, furrowed \\
Color & Outer surface - brownish black and inner \\
& surface - reddish brown \\
Taste & Bitter \\
Odor & Not characteristics \\
Fracture & Laminated \\
Texture & Rough \\
\hline
\end{tabular}

$\begin{array}{ll}\text { Table 2: Macroscopic characteristics of stem bark of } \\ \text { Tecomella undulata (Sm.) Seem. } \\ \text { Shape } & \text { Curved } \\ \text { Size } & 13-14 \mathrm{~cm} \\ \text { Surface } & \begin{array}{l}\text { Longitudinally irregularly fissured, attached } \\ \text { rhytidoma }\end{array} \\ \text { Color } & \begin{array}{l}\text { Outer surface - blackish and inner } \\ \text { surface - blackish brown }\end{array} \\ \text { Taste } & \text { Bitter } \\ \text { Odor } & \text { Not characteristics } \\ \text { Fracture } & \text { Outer splintery, inner fibrous } \\ \text { Texture } & \text { Rough }\end{array}$

Table 3: Macroscopic characteristics of powder of stem bark of Rhododendron arboreum Sm.

\begin{tabular}{ll} 
Color & Brown \\
Taste & Bitter \\
Odor & Mild characteristics \\
Texture & Rough \\
\hline
\end{tabular}

Table 4: Macroscopic characteristics of powder of stem bark of Tecomella undulata (Sm.) Seem.

\begin{tabular}{ll} 
Color & Brown \\
Taste & Bitter \\
Odor & Mild characteristics \\
Texture & Smooth \\
\hline
\end{tabular}


definition of "pratinidhi dravya"(substitute), when a dravya is abhava (unavailable), ${ }^{[15]}$ then any other drug possessing similar/identical properties such as Rasa (taste), Guna (properties), Veerya (potency), and Vipaka (metabolites) can be substituted in the absence of the original drug. ${ }^{[16]}$

Rhododendron arboreum $\mathrm{Sm}$. of family Ericaceae is the national flower of Nepal locally known as Laligurans and is the state tree of Uttarakhand where it is known as Burans. It is an evergreen tree of $7.5 \mathrm{~m}$ to $14 \mathrm{~m}$. in height and 2-4 m. in girth. In its native land, huge trees of $R$. arboreum grow to a height of $25 \mathrm{~m}$ or more. ${ }^{[13]} \mathrm{It}$ is reported that the folklore traditional practitioners of Nepal are using the plant $R$. arboreum $\mathrm{Sm}$. for the treatment of jaundice. Guransa ( $R$. arboreum) is also mentioned as Rohitaka in Chandra Nighantu, a famous manuscript written in Nepali language. As T. undulata is endangered, it is of at most important to find newer, more easily available, and effective substitute. Hence, this study has been taken up to evaluate and compare $R$. arboreum $\mathrm{Sm}$. and T. undulata (Sm.) Seem. pharmacognostically as substitute.

\section{MATERIALS AND METHODS}

\section{Plant Materials}

\section{Collection of plant materials}

The barks of the drug Rohitaka (T. undulata Sm. (Seem.) were collected from its natural habitat of Jaipur, Rajasthan, in the

Table 5: Powder microscopy of Rhododendron arboreum Sm. and Tecomella unduala (Sm.) Seem

\begin{tabular}{ll} 
Rhododendron arboreum & Tecomella unduala \\
\hline Parenchyma with starch & Parenchyma with starch \\
Parenchyma with cell & Parenchyma with cell \\
content & content \\
Transversely cut cork & Obliquely cut cork cells \\
Parenchyma cells with & Phloem fibers \\
medullary ray & \\
Prismatic crystals & Sclereids \\
& Calcium oxalate crystals \\
& Starch \\
\hline
\end{tabular}

month of February, and the barks of the drug $R$. arboreum Sm. were collected from its natural habitat of Pharping, Kathmandu, Nepal, in the month of April 2017. Their authentication was confirmed from the Department of Dravyaguna, Shri Dharmasthala Manjunatheshwara College of Ayurveda and Hospital, Hassan, with reference no. SDMCAH-DG/2017/17 dated 07-06-2017. The obtained barks were cut into pieces of variable length and diameter. They were kept for drying approximately for 15 days under sunlight.

\section{Pharmacognostical Study ${ }^{[17,18]}$}

\section{Macroscopic/organoleptic evaluation}

Macroscopical or organoleptic evaluation means the study of external morphology, its shape and size, color and external markings, fracture, internal color, odor, and taste of the drug. This study for the barks of both drugs was conducted at the Department of Dravyaguna, Shri Dharmasthala Manjunatheshwara College of Ayurveda and Hospital, Hassan. The external features of the test samples were documented using Canon IXUS digital camera.

\section{Microscopic evaluation}

Sample was preserved in fixative solution. The fixative used was formalin (FAA) (FAA $-5 \mathrm{ml}+$ acetic acid $-5 \mathrm{ml}+70 \%$ ethyl alcohol $-90 \mathrm{ml}$ ). The materials were left in FAA for more than $48 \mathrm{~h}$. The preserved specimens were cut into thin transverse section using a sharp blade and the sections were stained with safranin. The slides were also stained with iodine in potassium iodide for the detection of starch. Transverse sections were photographed using Zeiss AXIO trinocular microscope attached with Zeiss AxioCam camera under bright field light. Magnifications of the figures are indicated by the scale bars.

\section{Powder Microscopy}

A pinch of powder was warmed with drops of chloral hydrate on a microscopic slide and mounted in glycerin. Slides observed under microscope and diagnostic characters were observed and photographed using Zeiss AXIO Trinocular Microscope attached with Zeiss AxioCam camera under bright field light. Magnifications of the figures were indicated by the scale bars.

\begin{tabular}{|c|c|c|c|}
\hline \multirow[t]{2}{*}{ Physical parameters } & \multirow{2}{*}{$\begin{array}{c}\text { Results } n=3 \% \text { w/w } \\
\text { Rhododendron arboreum }\end{array}$} & \multirow{2}{*}{$\begin{array}{c}\text { Results } n=3 \% \text { w/w } \\
\text { Tecomella undulata }\end{array}$} & \multirow[t]{2}{*}{ API standard for Tecomella undulata } \\
\hline & & & \\
\hline Foreign matter & Not found & Not found & Not $>2 \%$ \\
\hline Total ash & 1.5 & 5 & Not $>12 \%$ \\
\hline Acid-insoluble ash & 0.5 & 1 & Not $>1 \%$ \\
\hline Alcohol-soluble extract & 7.5 & 11 & Not $<10 \%$ \\
\hline Water-soluble extract & 4.25 & 15.5 & Not $<15 \%$ \\
\hline Loss on drying & 11.75 & 1.25 & \\
\hline
\end{tabular}




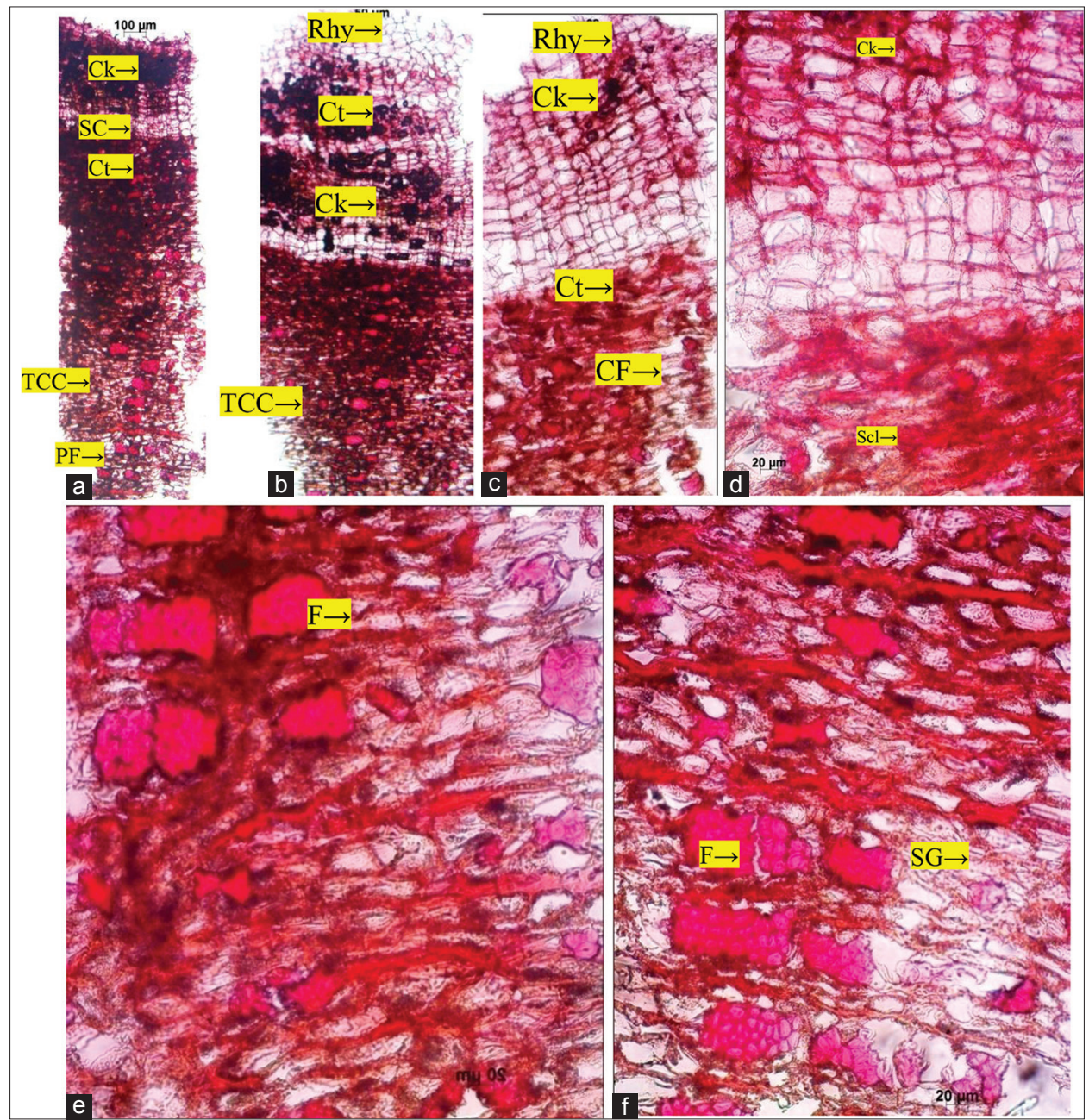

Figure 3: (a) T.S of stem bark of Tecomella undulata, (b) Portion of stem bark enlarged, (c) cork and cortex, (d) cortex containing sclereids, (e) Phloem fibers and starch grains, (f) Group of fibers. Ck - cork, Ct - cortex, F - fibers, SC - stone cells, Scl - sclereids, $S G$ - starch grains

\section{Analytical Study ${ }^{[17,18]}$}

\section{Physical evaluation}

\section{Loss on drying at $105^{\circ} \mathrm{C}$}

About $10 \mathrm{~g}$ of sample was placed in tarred evaporating dish. It was dried at $105^{\circ} \mathrm{C}$ for $5 \mathrm{~h}$ in hot air oven and weighed. The drying was continued until difference between two successive weights was not more than 0.01 after cooling in desiccator. The percentage of moisture was calculated with reference to weight of the sample.

\section{Total ash}

About $2 \mathrm{~g}$ of sample was incinerated in a tarred platinum crucible at temperature not exceeding $450^{\circ} \mathrm{C}$ until carbon free ash is obtained. The percentage of ash was calculated with reference to weight of the sample.

\section{Acid insoluble ash}

To the crucible containing total ash, $25 \mathrm{ml}$ of dilute $\mathrm{HCl}$ was added and heated for few minute. Then, insoluble matter on Ashless Filter Paper (Whatman 41) was collected and washed with hot water. The filter paper containing the insoluble matter was transferred to the original crucible and dried on a hot plate and ignited to constant weight. After that, the residue was allowed to cool in suitable desiccator for $30 \mathrm{~min}$ and weighed without delay. At last, the content of acid insoluble ash with reference to the air dried drug was calculated.

\section{Alcohol-soluble extract}

Weigh accurately $4 \mathrm{~g}$ of the sample in a glass stoppered flask. Add $100 \mathrm{ml}$ of distilled alcohol (approximately 95\%). Shake occasionally for $6 \mathrm{~h}$. Allow to stand for $18 \mathrm{~h}$. Filter rapidly taking care not to lose any solvent. Pipette out $25 \mathrm{ml}$ of the filtrate in a pre-weighed $100 \mathrm{ml}$ beaker. Evaporate to dryness on a water bath. Keep it in an air oven at $105^{\circ} \mathrm{C}$ for $6 \mathrm{~h}$, cool in desiccator for $30 \mathrm{~min}$, and weigh. Calculate the percentage of alcohol extractable matter of the sample. Repeat the experiment twice, and take the average value.

\section{Water-soluble extract}

About $4 \mathrm{~g}$ of the sample was weighed in a glass stoppered flask, and $100 \mathrm{ml}$ of distilled water was added and shaken occasionally for $6 \mathrm{~h}$. After $6 \mathrm{~h}$, it was allowed to stand for $18 \mathrm{~h}$. 
Next day, it was filtered rapidly taking care not to lose any solvent. Then, pipette out $25 \mathrm{ml}$ of the filtrate in a pre-weighed $100 \mathrm{ml}$ beaker. It was kept in to evaporate to dryness on a water bath. After dryness, it was kept in an air oven at $105^{\circ} \mathrm{C}$ for $6 \mathrm{~h}$. At last, it was cooled in a desiccator and weighed. The same procedure was repeated twice and the average value was noted.

\section{Chemical Evaluation}

\section{Preliminary phytochemical tests ${ }^{[18]}$}

- Tests for alkaloids:

a. Dragendorff's test: To a few $\mathrm{mg}$ of extract dissolved in alcohol, a few drops of acetic acid and Dragendorff's reagent were added and shaken well. An orange-red precipitate formed indicates the presence of alkaloids.

b. Wagner's test: To a few mg of extract dissolved in acetic acid, a few drops of Wagner's reagent were added. A reddish-brown precipitate formed indicates the presence of alkaloids.

c. Mayer's test: To a few mg of extract dissolved in acetic acid, a few drops of Mayer's reagent were added. A dull white precipitate formed indicates the presence of alkaloids.

d. Hager's test: To a few mg of extract dissolved in acetic acid, $3 \mathrm{ml}$ of Hager's reagent was added, and the formation of yellow precipitate indicates the presence of alkaloids.

- Tests for carbohydrates:

a. Molisch's test: To the extract, $1 \mathrm{ml}$ of $\alpha$-naphthol solution and concentrated sulfuric acid were added along the sides of test tube. Violet color formed at the junction of the two liquids indicates the presence of carbohydrates.

b. Fehling's test: A few mg of extract was mixed with equal quantities of Fehling's solution A and B. The mixture was warmed on a water bath. The formation of a brick red precipitate indicates the presence of carbohydrates.

c. Benedict's test: To $5 \mathrm{ml}$ of Benedict's reagent, a few $\mathrm{mg}$ of extract was added and boiled for $2 \mathrm{~min}$ and cooled. Formation of a red precipitate indicates the presence of carbohydrates.

- Test for steroids:

a. Liebermann-Burchard test: To the extract dissolved in chloroform, $1 \mathrm{ml}$ of acetic acid and $1 \mathrm{ml}$ of acetic anhydride were added, then heated on a water bath, and cooled. Few drops of concentrated sulfuric acid were added along the sides of the test tube. Appearance of bluish green color indicates the presence of steroids.

b. Salkowski test: The extract was dissolved in chloroform and an equal volume of concentrated sulfuric acid was added. Formation of bluish red to cherry red color in chloroform layer and green fluorescence in the acid layer indicates the presence of steroids.
- Test for saponins:

a. To a few mg of extract, distilled water was added and shaken. Stable froth formation indicates the presence of saponin.

- Test for tannins:

a. To the extract, a few drops of dilute solution of ferric chloride were added, and the formation of dark blue color shows the presence of tannins.

- Test for flavonoids:

a. Shinoda's test: To the extract in alcohol, a few magnesium turnings and few drops of concentrated. hydrochloric acid were added and heated on a water bath. Formation of red to pink color indicates the presence of flavonoids.

- Test for phenol:

a. To the extract in alcohol, added two drops of alcoholic ferric chloride. Formation of blue to blueblack indicates the presence of phenol.

- Test for coumarins:

a. To the extract in alcohol, a few drops of $2 \mathrm{~N}$ sodium hydroxide solution were added. Dark yellow color formation indicates the presence of coumarins.

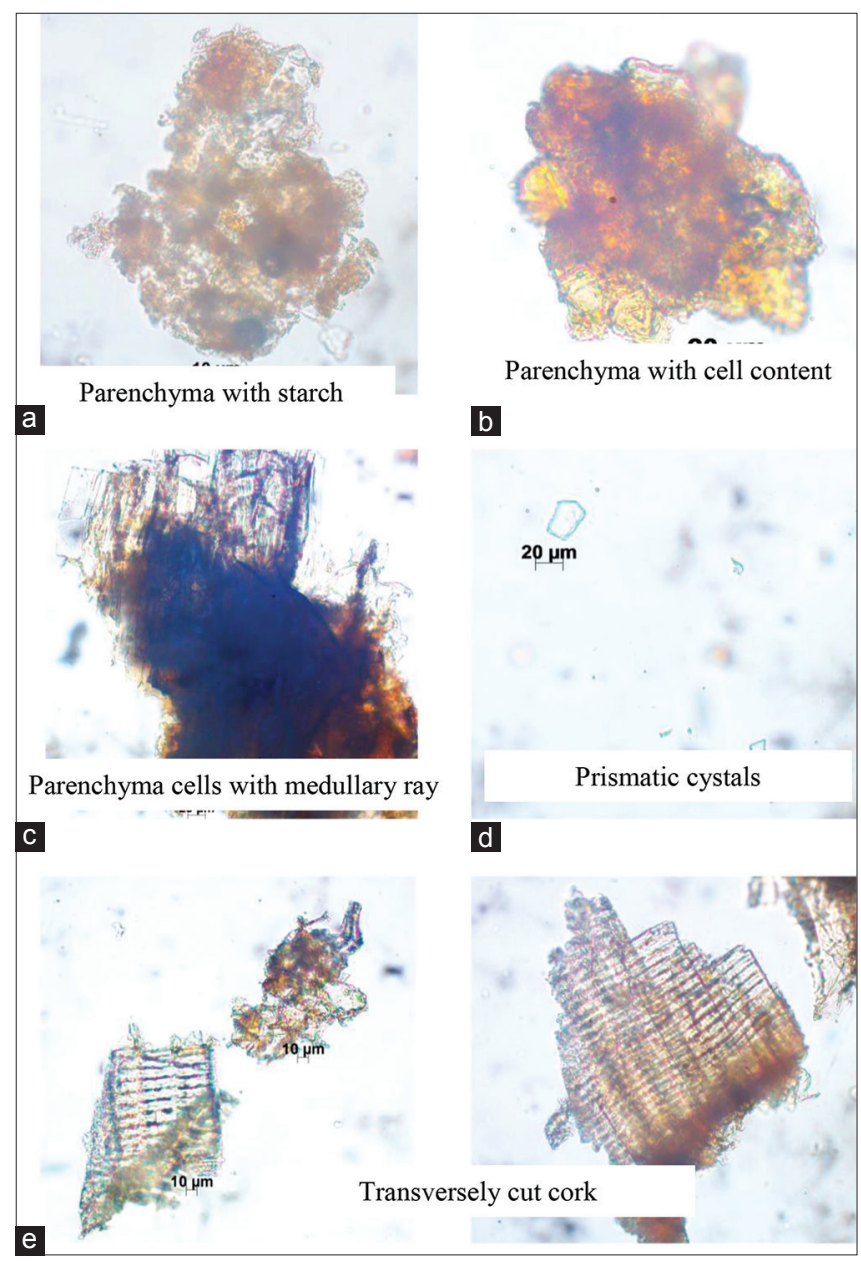

Figure 4: Powder microscopy of Rhododendron arboretum, (a) parenchyma with starch, (b) parenchyma with cell content, (c) parenchyma cells with medullary ray cells, (d) prismatic crystals, (e) transversely cut cork 


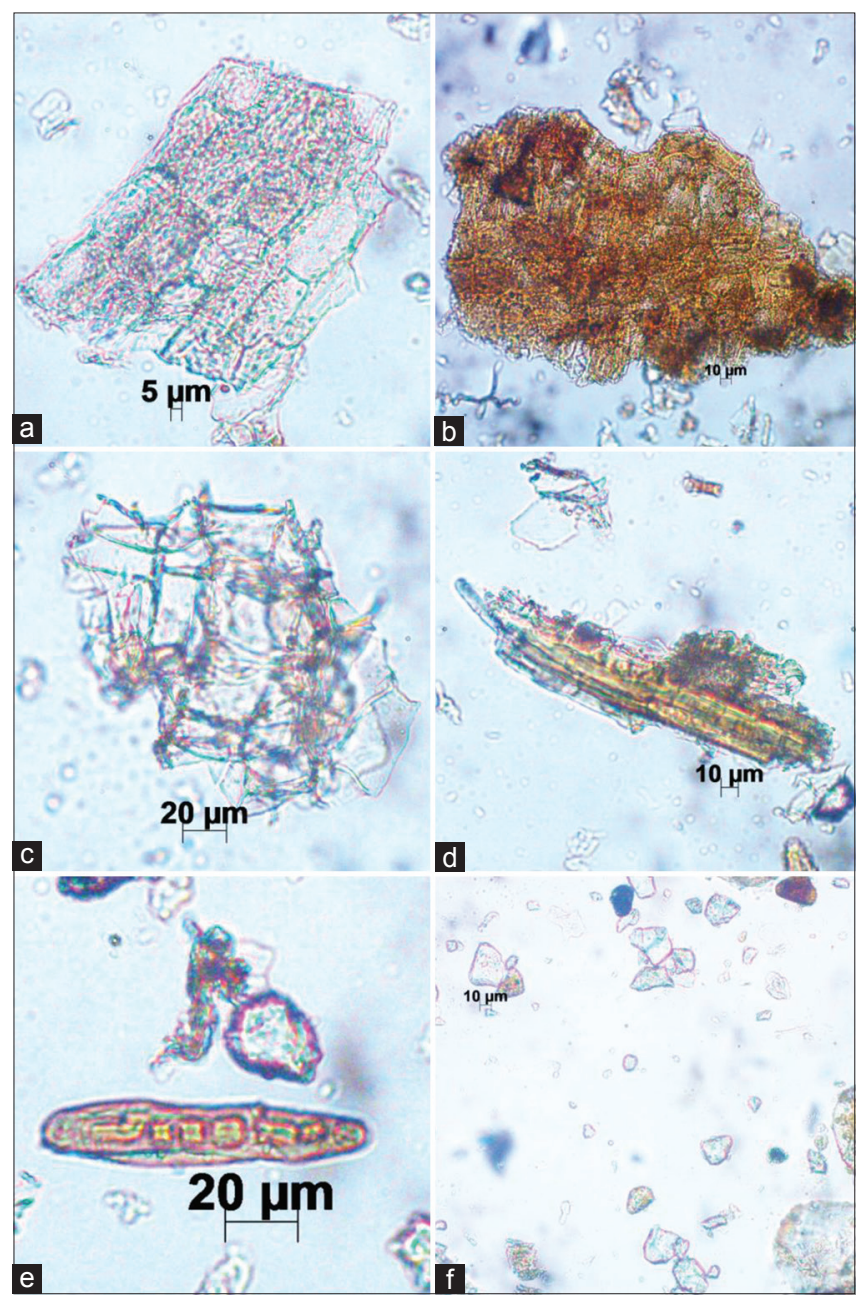

Figure 5: Powder microscopy of Tecomella undulata; (a) Parenchyma with starch, (b) parenchyma with cell content, (c) cork cells obliquely cut, (d) phloem fibers, (e) Sclereids, (f) calcium oxalate crystals and starch

- Test for triterpenoids:

a. The extract was warmed with Tin bits and few drops of thionyl chloride. The formation of pink color indicates the presence of triterpenoids.

- Test for carboxylic acid:

a. Extract dissolved in water is treated with sodium bicarbonate. Brisk effervescence indicates the presence of carboxylic acid.

- Test for resin:

a. Few $\mathrm{mg}$ of the sample was mixed with water and acetone. Turbidity indicates the presence of turbidity.

- Test for quinine:

a. A few mg of alcohol extract was treated with $0.5 \%$ of sodium hydroxide. Deep coloration such as pink, purple, or red indicates the presence of quinine.

\section{HPTLC}

\section{Comparison of R. arboreum and T. undulata}

About $1 \mathrm{~g}$ of each of powdered samples of $R$. arboreum and T. undulate was dissolved in $20 \mathrm{ml}$ ethanol and kept for cold percolation for $24 \mathrm{~h}$ and filtered. 4 and $8 \mu \mathrm{l}$ of the above samples were applied on a pre-coated silica gel F254 on aluminum plates to a band width of $7 \mathrm{~mm}$ using Linomat 5 TLC Applicator. The plate was developed in toluene:chloroform:formic acid:methanol (6.0:0.5:0.2:1.5). The developed plates were visualized in short UV and long $\mathrm{UV}$, then derivatized with vanillin sulfuric acid reagent, and scanned under $254 \mathrm{~nm}$ and $366 \mathrm{~nm}$, under white light at $620 \mathrm{~nm}$. Rf, color of the spots, and densitometric scan were recorded.

\section{RESULTS AND DISCUSSION}

Rohitaka is the famous drug for hepatic disorders. Its genuine source is identified as T. undulata ( $\mathrm{Sm}$.) Seem. Various researchers suggested and reported that it should be designated as a "reserved" species to promote its conservation. Similarly, Hussain et al. compiled a "red data book" to determine the threatened status of native plants of Karachi. Hence, conservation of this plant species is the need of the hour. ${ }^{[14,19]}$

Various other species are abundantly used as substitutes of T. undulata. A. rohituka or A. polystachia is a commonly used substitute. ${ }^{[10]}$ In Nepal, stem bark of $R$. arboreum $\mathrm{Sm}$. commonly known as Lali Guransa is used as folklore medicine of jaundice. Stem bark of $R$. arboreum $\mathrm{Sm}$. is commonly found by the name of Rohitaka. $R$. arboreum $\mathrm{Sm}$. is abundantly found in Himalayan region of Nepal. As T. undulata is endangered, it is of at most important to find newer, more easily available, and effective substitute. Hence, this study has been taken up.

\section{Pharmacognostical Study}

Pharmacognostical study includes macroscopic/organoleptic and microscopic of the evaluation of drugs.

\section{Macroscopic, Organoleptic, and Microscopic Study}

In the present study, the suggested procedure of organoleptic evaluation comprising test, odor, appearance, texture, etc., was used in identifying the drug. Blackish brown-colored bark with rhytidoma and longitudinal fissures with curved shape with bitter taste and fibrous fracture is organoleptic characteristics of T. undulata. Brownish-colored, rough surface, and flat or slightly curved bark with laminar fracture and bitter taste is characteristic features of the bark of $R$. arboreum [Tables 1 and 2]. The stem bark pieces of $T$. undulata were $13-14 \mathrm{~cm} \times 2-3 \mathrm{~cm}$, while pieces of bark of R. arboreum were 9-10 $\mathrm{cm} \times 3-4 \mathrm{~cm}$ [Figure 1].

The microscopic study of transversally cut section of the bark of $T$. undulata revealed outer rhytidoma, wider cork having rectangular cells, and stone cells. Cortex consists of cortical 
fibers, sclereids, and tannin containing cells. Phloem is divided into outer and inner phloem containing phloem fibers traversed with cortex. Starch grains were also found in cortex and phloem parenchyma [Figure 3].

T.S. of $R$. arboreum showed outer rhytidoma and wide cork consisting of rectangular and tangentially elongated cells; cortex and phloem tissue traversed with groups of thickwalled lignified fibers; phloem a wide zone comprising of phloem parenchyma, fibers and medullary rays. Phloem is divided into outer phloem and inner phloem. Stone cells and tannin containing cells are traversed in cortex and phloem

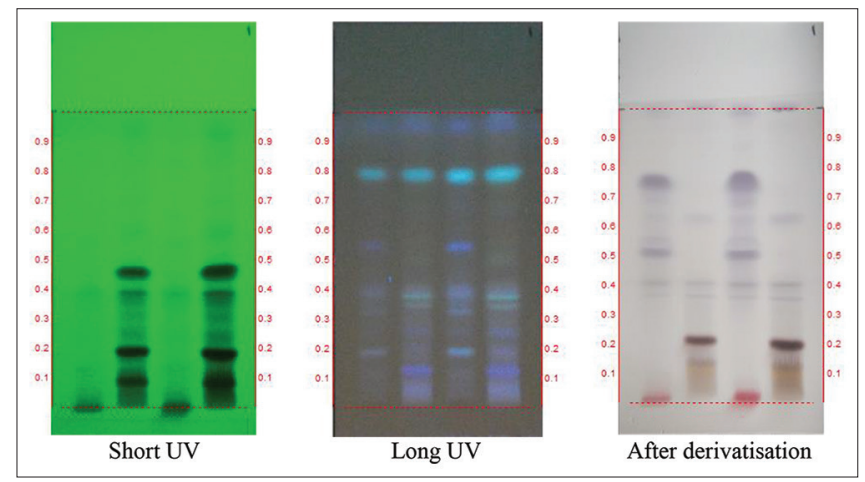

Figure 6: High-performance thin-layer chromatography photo documentation of ethanol extract of Rhododendron arboreum bark and Tecomella undulata bark. track 1 - Rhododendron arboreum - $4 \mu \mathrm{l}$, track 2 - Tecomella undulate - $4 \mu \mathrm{l}$, track 3 - Rhododendron arboreum-8 $\mathrm{\mu l}$, track 4 -Tecomella undulata - $8 \mu \mathrm{l}$, Solvent system - toluene: chloroform:formic acid: methanol (6.0:0.5:0.2:1.5)

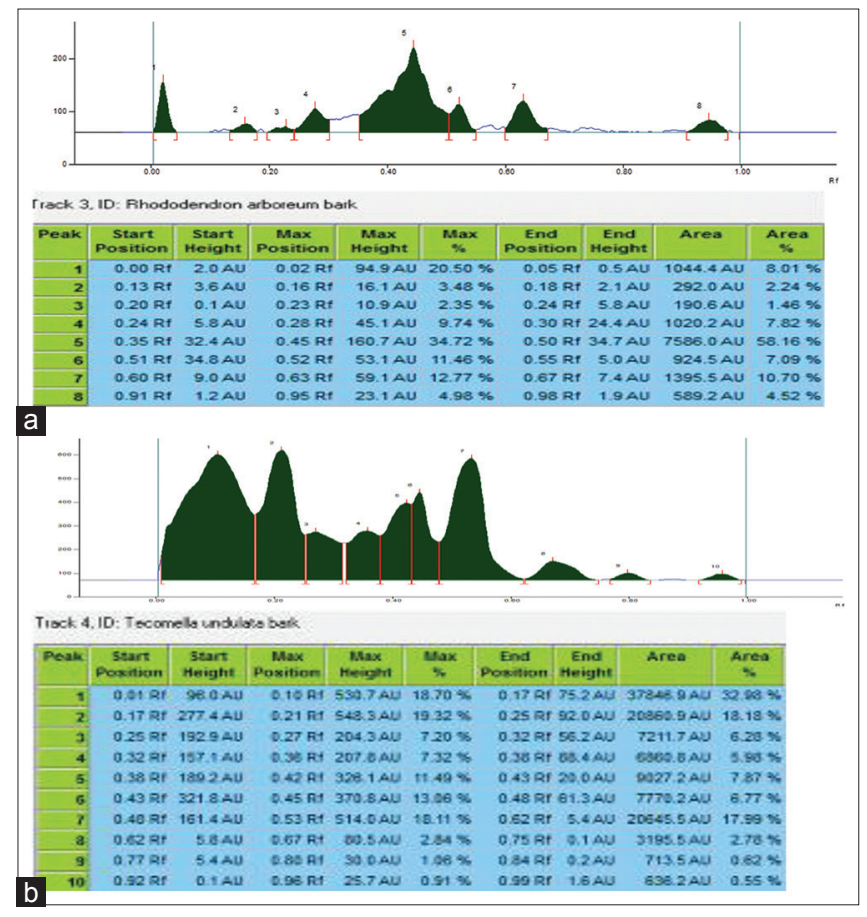

Figure 7: Densitometric scan at $254 \mathrm{~nm}$. (a) Rhododendron arboretum, (b) Tecomella undulate parenchyma also consisting crystals of calcium oxalates [Figure 2]. The macroscopic and organoleptic characteristics of powder of Rhododendron arboreum and Tecomella undulata are mentioned in Tables 3 and 4 .

The powder microscopy of Tecomella unduala revealed the presence of parenchyma with starch, parenchyma with cell content, cork cells, phloem fibers, sclereids, calcium oxalate crystals, and starch grains, while the powder microscopy of $R$. arboreum showed the presence of parenchyma with starch, parenchyma with cell content, parenchyma cells with medullary ray prismatic crystals, and transversely cut cork cells [Figures 4 and 5, Table 5].

In a previous study, powder microscopy of $T$. undulata showed some important features such as unicellular glandular trichomes, periderm cells, and sclereids/scleretic cells. ${ }^{[20]} T$. undulate powder showed prismatic calcium oxalate crystals with rare sclereids, and the absence of stone cells, hexagonal-shaped cork cells, and dark brown pigmentation of tannin was observed in medullary rays of powder of T. undulata. ${ }^{[21]}$

\section{Analytical Study}

This study includes physical and chemical evaluation along with the chromatographic analysis. The findings of physiochemical analysis of $T$. undulata are within standard limit which proves it genuinity, while physiochemical parameter standard reference for $R$. arboreum bark is not mentioned, so it can be taken as reference. Extractive values for $T$. undulata are higher than $R$. arboreum, which shows more solubility of previous one in both water and alcohol [Table 6].

Table 7: Results of preliminary phytochemical tests

\begin{tabular}{lcc} 
Test & $\begin{array}{c}\text { Rhododendron } \\
\text { arboreum }\end{array}$ & $\begin{array}{c}\text { Tecomella } \\
\text { Undulata }\end{array}$ \\
\hline Alkaloid & + & + \\
Steroid & - & - \\
Carbohydrate & - & + \\
Tannin & - & - \\
Flavonoids & + & - \\
Saponins & + & - \\
Terpenoid & + & - \\
Coumarins & - & - \\
Phenol & + & + \\
Carboxylic acid & - & - \\
Resins & + & - \\
Quinone & - & + \\
Amino acids & - & - \\
\hline
\end{tabular}

+: Present, -: Absent 


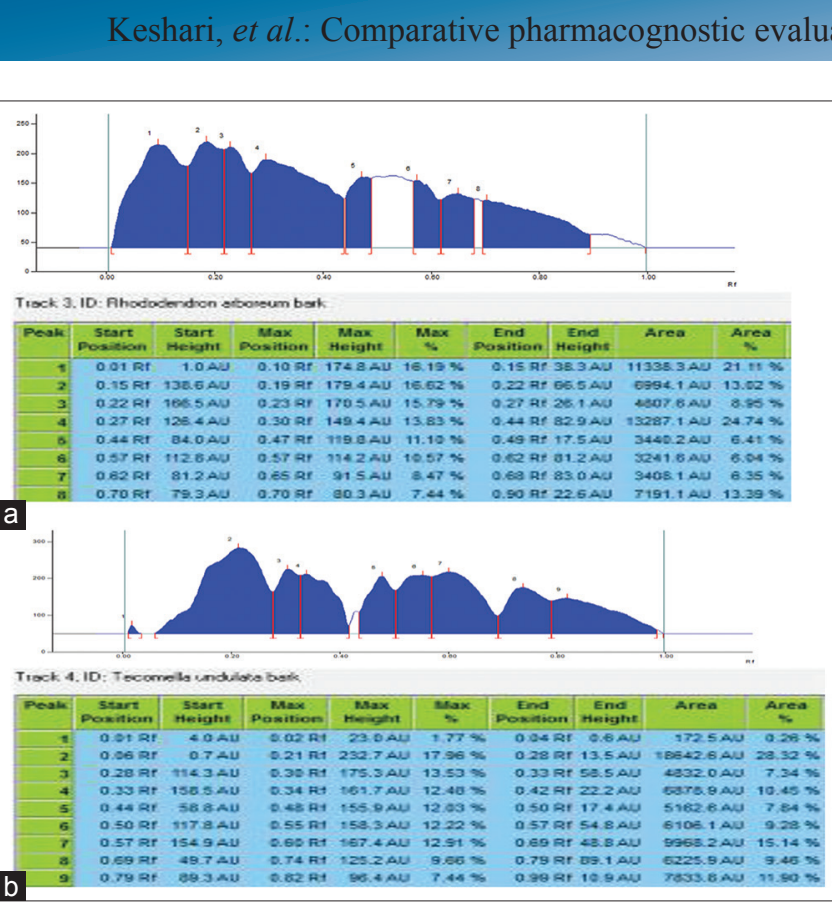

Figure 8: Densitometric scan at $366 \mathrm{~nm}$. (a) Rhododendron arboretum, (b) Tecomella undulate

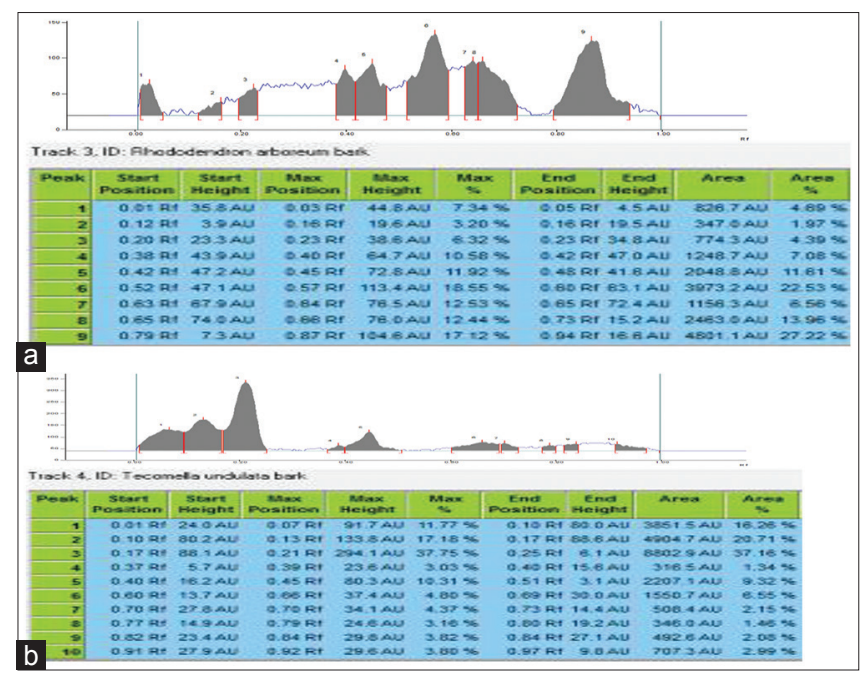

Figure 9: Densitometric scan at $620 \mathrm{~nm}$. (a) Rhododendron arboretum, (b) Tecomella undulate

\section{Phytochemical Study}

Preliminary phytochemical screening is carried out to establish chemical profile of a crude drug and detect the various plant constituents. The chemical tests are used to identify crude drugs to determine purity.

The extractive sample of the test drug T. undulata shown the presence of alkaloids, carbohydrates, phenols, tannins, and quinone and the extractive sample of $R$. arboreum shown the presence of alkaloids, tannins, flavonoids, saponins, terpenoid, phenol, and resins [Table 7].

The previous phytochemical study of $T$. undulata had shown the presence of glycosides, phenolic acid, flavonoids, carbohydrate naphthoquinones, and tannin. ${ }^{[21]}$
Similarly, the previous study of $R$. arboreum had shown the presence of alkaloids, steroids, terpenoids, anthraquinones, tannins, saponins, glycosides, and reducing sugars. ${ }^{[22]}$ From the analysis of the results obtained from the preliminary phytochemical screening conducted in this study, carbohydrates, alkaloids, tannins, and phenols are the chemical constituents found in both the drugs, while flavonoids, saponins, and terpenoid are found only in $R$. arboretum extracts and quinone is found in T. undulata bark extracts [Table 7].

\section{Chromatography Study}

This method helps in separation of chemical constituents between two phases: A mobile and a stationary phase. It is an important analytical tool for qualitative and quantitative analysis of the drugs. In this study, HPTLC method was conducted. The plates developed were visualized in UV $254 \mathrm{~nm}$ and $366 \mathrm{~nm}$ and then post-derivatized.

The HPTLC fingerprinting of $R$. arboreum bark extracts revealed the presence of 5 spots and T. undulata showed 10 spots when observed under short UV with different intensities of light and dark green. When observed under long $\mathrm{UV}, R$. arboreum showed 7 spots and T. undulata showed 11 spots which were fluorescent, deep blue, or aqueous blue in color [Figure 6 and Table 8].

After derivatization with vanillin sulfuric acid, when the samples observed under white light, $R$. arboreum showed 7 spots and T. undulata showed 5 spots, all deep purple in color as mentioned in Table 8.

Densitometric scan at $254 \mathrm{~nm}, R$. arboreum, showed 8 peaks among which three major peaks are with Rf of 0.45 (34.72\%), $0.02(20.50 \%)$, and $0.63(12.77 \%) ;$ T. undulata showed total of 10 peaks of which $\mathrm{Rf}$ of $0.21(19.32 \%), 0.10(18.70 \%)$, and $0.53(18.11 \%)$ are prominent [Figure $7 \mathrm{a}$ and $\mathrm{b}$ ]. Densitometric scan at $366 \mathrm{~nm} R$. arboreum showed a total of 8 peaks, among which Rf 0.19 (16.62\%), 0.10 (16.19\%), and $0.23(15.79 \%)$ are, respectively, three maximum covering area. T. undulata showed 9 peaks, of which peak with $\operatorname{Rf} 0.21(17.96 \%), 0.30(13.53 \%)$, and $0.60(12.91 \%)$ is major area showed in Figure $8 \mathrm{a}$ and $\mathrm{b}$. Densitometric scan at $620 \mathrm{~nm}$ following derivatization, $R$. arboreum, showed 9 peaks, among these Rf of 0.57 (18.55\%), 0.87 (17.12\%), and $0.64(12.53 \%)$ are major peaks; $T$. undulata showed a total of 10 peaks; among them, Rf of 0.21 (37.75\%), 0.13 (17.18\%) and $0.07(11.77 \%)$ are the major peaks as shown in Figure 9a and b. Three-dimensional chromatogram, (a) At $254 \mathrm{~nm}$, (b) At $366 \mathrm{~nm}$, (c) At $620 \mathrm{~nm}$ are mentioned in Figure 10.

The present study revealed that there are 18 active phytoconstituents in R. arboreum barks and 24 in T. undulata. On densitometric scan, in $R$. arboreum, following phytoconstituents of $\mathrm{Rf}$ of $0.10,0.16,0.19,0.23,0.28,0.30$. $0.40,0.45,0.47,0.52,0.57,0.63,0.64,0.65,0.66,0.70$, 
Keshari, et al.: Comparative pharmacognostic evaluation of Tecomella undulata and Rhododendron arboreum

Table 8: Rf values of sample of Rhododendron arboreum bark and Tecomella undulata

\begin{tabular}{|c|c|c|c|c|c|}
\hline \multicolumn{2}{|l|}{ Short UV } & \multicolumn{2}{|c|}{ Long UV } & \multicolumn{2}{|c|}{ Post derivatization } \\
\hline Rhododendron & $\begin{array}{c}\text { Tecomella } \\
\text { undulata }\end{array}$ & Rhododendron & $\begin{array}{c}\text { Tecomella } \\
\text { undulata }\end{array}$ & Rhododendron & $\begin{array}{c}\text { Tecomella } \\
\text { undulata }\end{array}$ \\
\hline- & - & - & 0.06 (F. blue) & - & - \\
\hline- & 0.08 (D. green) & - & 0.08 (F. blue) & - & - \\
\hline- & - & - & - & - & - \\
\hline 0.13 (L. green) & - & - & 0.13 (F. blue) & - & 0.13 (D. purple) \\
\hline- & 0.19 (D. green) & 0.19 (FD. Blue) & 0.19 (F. blue) & - & - \\
\hline- & - & - & - & - & 0.21 (D. purple) \\
\hline 0.24 (L. green) & 0.24 (L. green) & - & - & - & - \\
\hline- & - & 0.25 (FD. Blue) & 0.25 (F. blue) & - & - \\
\hline- & 0.31 (L. green) & - & - & - & - \\
\hline- & - & 0.33 (FD. Blue) & 0.33 (F. blue) & - & - \\
\hline- & - & - & - & 0.35 (D. purple) & 0.35 (D. purple) \\
\hline 0.38 (D. green) & 0.38 (D. green) & 0.38 (FD. Blue) & 0.38 (FD. Green) & - & - \\
\hline- & - & - & - & 0.41 (D. purple) & 0.41 (D. purple) \\
\hline- & 0.47 (D. green) & - & - & - & - \\
\hline- & - & - & 0.50 (FL. Brown) & 0.50 (D. purple) & - \\
\hline 0.56 (L. green) & - & 0.56 (FD. Blue) & 0.56 (FL. Brown) & 0.56 (D. purple) & - \\
\hline- & 0.59 (L. green) & - & - & - & - \\
\hline- & - & - & - & 0.62 (D. purple) & 0.62 (D. purple) \\
\hline- & - & - & - & 0.68 (D. purple) & - \\
\hline- & 0.70 (L. green) & - & - & - & - \\
\hline- & - & - & - & 0.76 (D. purple) & - \\
\hline- & - & 0.79 (F aqua. Blue) & 0.79 (F aqua. Blue) & - & - \\
\hline 0.83 (L. green) & - & - & - & - & - \\
\hline- & 0.85 (L. green) & - & - & - & - \\
\hline- & 0.92 (L. green) & - & - & - & - \\
\hline- & - & 0.96 (FD. Blue) & 0.96 (F. blue) & - & - \\
\hline
\end{tabular}

D: Dark, L: Light, F: Fluorescent

0.87 , and 0.95 were visible. Similarly, in T. undulata, Rf of following constituents was detected; $0.02,0.07,0.10,0.21$, $0.27,0.30,0.34,0.36,0.39,0.42,0.45,0.48,0.53,0.60,0.66$ $0.67,0.70,0.74,0.79,0.80,0.82,0.84,0.92$, and 0.96 .

Among all the active phytoconstituents found in both $R$. arboreum and $T$. undulata, three phytoconstituents are common having similar Rf value of $0.30,0.45$, and 0.66 on densitometric scan.

\section{CONCLUSION}

The genuine source of Rohitaka is identified as T. undulata (Sm.) Seem. However, due to non-availability of the genuine source, various other drugs are used as substitute. Stem bark of $R$. arboreum $\mathrm{Sm}$. is commonly found by the name of Rohitaka in herbal raw drugs trade in Nepal. The rationality behind selection of Pratinidhi Dravya (substitute drug) is based on similarity in Rasa, Guna, Veerya, and Vipaka with that of original drug. On organoleptic evaluation, both drugs are bitter in taste substantiated the similarity in Rasa. The pharmacognostic and analytical studies have confirmed the genuinity and purity of both the drugs ( $R$. arboreum $\mathrm{Sm}$. and T. undulata [Sm.] Seem.). Both the drugs have few common phytochemicals such as carbohydrates, alkaloids, tannins, and phenols which are responsible for their pharmacological actions. Chromatographic study showed the presence of 18 phytoconstituents in $R$. arboreum and 24 phytoconstituents in T. undulata extracts, and among them, three phytoconstituents having $\mathrm{Rf}$ of $0.30 .0 .45,0.66$ are common.

\section{REFERENCES}

1. Samhita AC, Dutta C. Ayurveda dipika vyakhya. In: Shastri K, Pandey GS, editors. Vidyotani Hindi Tika. Varanasi: Chaukhamba Sanskrit Sansthan; 2004. 




Figure 10: Three-dimensional chromatogram, (a) At 254 nm, (b) At 366 nm, (c) At 620 nm

2. Saushruta V. In: Shastri AD, editor. Sushruta Samhita. $11^{\text {th }}$ ed. Varanasi: Chaukhamba Sanskrit Sansthana; 1997

3. Murthy KR. Astanga Hridaya of Vagbhata. $3^{\text {rd }}$ ed., Vol. 2. Varanasi: Krishnadas Academy; 1998.

4. Murthy KR. Sharangdhara. Sharangdhara Samhita. $3^{\text {rd }}$ ed. Varanasi: Chaukhambha Orientalia; 1997.

5. Pandey GS, editor. Bhavamishra, Bhavaprakash Nighantu. $6^{\text {th }}$ ed. Varanasi: Chaukhambha Bharati Academy; 1988. p. 527-8.

6. Indradev T, Dayashankar T. Yogaratnakara. Vaidya Prabha Hindi Vyakha. $4^{\text {th }}$ ed. Varanasi: Chaukhambha Krishnadas Academy; 2013. p. 531-2, 832.

7. Shloka AV, Ojha J. Dhanwantari, Dhanwantari Nighantu. $2^{\text {nd }}$ ed. Varanasi: Chaukhamba Surbharati; 1996.p. 11920, 232.

8. Sngraha G, Varga A. Shloka Shodhal Vaidyacharya, Shodhal Nighantu. Varanasi: Chaukamba Orientalia; 1978. p. 136, 522.

9. Government of India, Ministry of Health and Family welfare, Department of Ayush. The Ayurvedic Pharmacoepea of India, $1^{\text {st }}$ ed., Vol 6. New Delhi: Government of India, Ministry of Health and Family welfare, Department of Ayush; 2008. p. 135-6.

10. Sharma PC, Yelne MB, Dennis TJ, editors. Rohitaka. In: Database on Medicinal Plants used in Ayurveda. Vol 6. New Delhi: Central Council for Research in Ayurveda and Siddha; 2002. p. 321-4.

11. Suman K, Singh N. Micropropagation of Tecomella undulata (Sm.) Seem. And genetic fidelity testing of in vitro raised plants. Asia Pac J Mol Biol Biotechnol 2014;22:191-8.
12. Mahalh SM, Jalilvand H, Sheikholeslami A, Kalbi S. Comparison of quantitative and qualitative properties of Tecomella undulata (Roxb) in two sites Shahnia and Moghdan in Bushehr Proviance. Tech J Eng App Sci 2013;3:602-7.

13. Available from: http://www.worldagroforestry.org/ treedb/AFTPDFS/Rhododendron_arboreum.PDF. [Last cited on 2018 Mar 14].

14. Richa D, Shekhawat GS. Critical review on Tecomella undulata: A medicinally potent endangered plant species of Indian Thar desert. Int $\mathrm{J}$ Curr Res 2012;4:36-44.

15. Giri CM. Concept of Abhava Pratinidhi Dravyas, a rational substitution of drugs - A review. Int $\mathrm{J}$ Adv Ayurveda 2013;2:148-61.

16. Shastri A, Shastri R, editor. Bhaishajya Ratnavali. $2^{\text {nd }}$ ed. Varanasi: Chaukhambha Sanskrit Samsthan; 2007. p. 39-40.

17. Kokate CK, Purohit AP, Gokhele SB. Pharmacognosy. Pune: Nirali Prakashan; 2014. p. 7.

18. Khandelwal KR, Sethi VK. Practical Pharmacogosy. $27^{\text {th }}$ ed. Pune: Nirali Prakashan; 2016.

19. Google Search-Tecomella Undulata - Wikipedia, the Free Encyclopedia. Available from: http://www. en.m.wikipedia.org $>$ wiki $>$ Tecoma. [Last cited on 2017 Dec 20].

20. Pundir S, Tomar SK, Mishra SH, Albert S, Jain M. Pharmacognostical standardization and chromatographic evaluation of Tecomella undulata stem bark. Int J Biol Pharm All Sci 2015;4:4499-511.

21. Nahida P, Dharya S, Vidhu A. Quality control and 
Keshari, et al.: Comparative pharmacognostic evaluation of Tecomella undulata and Rhododendron arboreum

comparative study of ayurvedic plant Tecomella undulata (sm.) Seem. With its adulterant Aphanamixis polystachya (Wall.). Int J Pharm Phytochem Res 2015;7:917-22.

22. Nisar M, Ali S, Qaisar M. Preliminary phytochemical screening of flowers, leaves, bark, stem and roots of Rhododendron arboreum. Middle East J Sci Res 2011;10:472-6.

Source of Support: Nil. Conflict of Interest: None declared. 